\title{
Conversational Implicature (Flouting the Maxims): Applying Conversational Maxims on Examples Taken from Non-Standard Arabic Language, Yemeni Dialect, an Idiolect Spoken at IBB City
}

\author{
Ahmed Mohammed Saleh Alduais \\ Department of English Language, King Saud University (KSU), Riyadh, Saudi Arabia \\ Email: ibnalduais@yahoo.com
}

Accepted: September 16, 2012 Published: October 22, 2012

Doi:10.5296/jsr.v3i2.2433 URL: http://dx.doi.org/10.5296/jsr.v3i2.2433

\begin{abstract}
Purpose: To investigate the fact that the theory of Conversational Implicature proposed by Austin and later on extended by Grice can be universal and can be applied to all languages of the world, an idiolect from the Arabic language in this case.
\end{abstract}

Method: Thirty minutes recorded conversation between the researcher and one of his friends who are from the same governorate and they nearly share the same non-standard Arabic. Namely, they both speak the Yemeni non-standard Arabic, an idiolect spoken at Ibb governorate. After that, the researcher has transcribed the recorded speech and then translating it into English. Needless to say, the analysis of the data has been based on both Austin's and Grice's principles of Pragmatics, Conversational Implicature theory.

Results: Illustrative examples for flouting the four maxims of speech were introduced and analyzed pragmatically. That is, it was explained in detail how the maxims of quantity, quality, manner and relation were flouted and an implicature from each was generated.

Conclusions: It was concluded that the claim our speech can be systematized and it has implicatures in one way but not in another is to some extent true. Thus, this theory can be applied to other idiolects of non-standard Arabic.

Keywords: Maxims of speech, Maxim of quantity, Maxim of quality, Maxim of relation, Maxim of manner, Conversational implicature theory, and Pragmatics. 


\section{Introduction}

Strictly speaking, we, you and I communicate with one another in our day-today life and simply understand each other without thinking in the way how we do understand each other. Put another away and with reference to both Austin's ideas and Grice's ideas, we usually if not sometimes always say something and mean either directly or indirectly something else. This distinction between what is said and what is meant was Austin's core idea of his early theory in Pragmatics.

Later on, Grice who is mainly Austin's student has made an attempt to go further. That is, to systematize how a hearer gets form what is said to what is meant, from the level of expressed meaning to the level of implied meaning. In this research paper, however, the researcher is going to apply some of the examples taken from the non-standard Arabic language, Yemeni dialect and idiolect spoken at IBB city on the Conversational Implicature theory and mainly flouting the maxims.

A number of the examples will be mentioned in Arabic and then translated into English and finally analyzed to see whether Grice's theory can be applicable to other languages rather than English or not. A decision will be made whether Grice's theory in Pragmatics in particular and other theories of Pragmatics in general can be considered as universal or they are only applicable to English language.

\section{Theoretical Background of the Study}

Since the early 1970s, Pragmatics has become an important field in linguistics though it was argued and still argued whether to consider it as a field of linguistics or not, (Collinge, 2001). In spite of this not until the 1980s, Pragmatics has started to appear in "textbooks on linguistics", (Thomas, 1995: p.1).

Principally, Austin, Grice and Searle are considered as the proponents of Pragmatics, each of which has published either a book or essay which has greatly influenced the study of Pragmatics and has lead in one way or another to the development of this field of study in linguistics. Nevertheless, many linguists and critics has argued against this field as a branch of philosophy rather than linguistics as its proponents and originators are philosophers rather than linguists, yet they have discussed and introduced it from the point of view of philosophy and logic rather than language study (linguistics).

From among those influential theories is Grice's theory of Conversational Implicature where in Grice attempts to show systematically how a person gets from what is said to what is meant, or from the expressed meaning to the implied meaning, (Thomas, 1995).

Horn and Ward (2005) introduce the implicature as the distinction between "the said and the meant- the implicated and the unsaid", (ibid: p. 1). Furthermore, they go on to say that 
implicature means the additional meaning or saying little and meaning more, (ibid).

In addition to what I have mentioned above, (Black, 2005) introduces the theories of Pragmatics and from among these theories he introduces Grice's theory of Conversational Implicature or (Cooperative Principle). According to Grice in Black, this principle works in four maxims: Quality, Quantity, Relation and Manner, each of which has some conditions which by an utterance can be measured.

Similar to the above opinions is Carston's one (2002) who agrees to the idea that Grice's theory has become influential yet has its spots of weakness. He summarized this theory by stating that Grice has made an attempt to make clear-cuts between what is said and what is implicated.

More importantly and which is our main concern in this research-paper is that Grice make a distinction between observing maxims and non-observance of the maxims and there are five cases where in maxims are not observed. According to Grice they are: flouting the maxim, violating the maxims, infringing the maxims, opting out the maxims and suspending the maxims. However, the case where in an implicature is generated (flouting the maxims) is considered as the most important one (Thomas: 1995) and it is our concern in this research-paper.

Basically, the process whereby an implicature is generated is referred to flouting a maxim, (Black, 2006). According to Grice, this happens blatantly and intentionally but with no intention to deceive or mislead the other party involved in the conversation. In the next part of this research-paper, each type of the maxims will be introduced, defined and then illustrated with at least two examples.

\section{Methods}

This study is purely qualitative where in collected data has been analysed based on the conversational implicature theory. The data was collected by tape-recording two cases whose mother tongue language is Arabic language, Yemeni Arabic language as the dialect, and Ibb city as the idiolect. The conversation between the two cases was general, that is spontaneous data elicitation and lasted for 30 minutes. The collected data was then transcribed in the native language (Arabic), translated into English and then certain examples were selected in accordance with the maxims of speech (flouting the maxims only). The study took place at King Saud University's Students Housing, Riyadh, Saudi Arabia.

\section{Results and Discussion}

\section{Example (1): (source in Arabic)}

$$
\begin{aligned}
& \text { انته ومن سافرك- انته و انور؟ أناف } \\
& \text { سافرك أنا وابلأخ أنور أنور } \\
& \text { وهو نوم.. نوووم }
\end{aligned}
$$

(Context) 
Ahmed and his friend Abdullwahab are talking about Abdullwahab's journey to Yemen and Ahmed is asking about the person whom he travelled with.

Example (1): (translated into English)

A: With who have you travelled?

AB: With brother Anwar.

AB: He was sleeping... slEEping.

Generally speaking and according to Grice's theory of Conversational Implicature mainly -non-observance of the maxim case, an implicature is generated only in the case of flouting the maxim. Basically, a maxim is flouted when a speaker fails to observe the maxim blatantly and of course with no intention to mislead or deceive the hearer. Additionally, Grice introduced four types of flouting a maxim: Quantity, Quality, Relation and Manner. The above example (1) is an example where in the maxim of quantity has been flouted.

Essentially, the maxim of quantity is flouted when a speaker gives either more or less information than it is required. Needless to say, this happens blatantly and an implicature is generated. However, we can notice that the speaker (A) has asked the speaker (AB) a particular question asking for a particular piece of information. That is, Ahmed who is the speaker (A) has asked Abdullwahab who is the speaker (AB) about the person(s) whom he travelled with and the answer must be specific like (with B or B and C). Consequently, the speaker $(\mathrm{AB})$ has provided more information than the situation demands. In other words, it is not Ahmed's question whether the person(s) whom Abdullwahab has travelled with was sleeping or not, he has only asked about the name. In spite of this, we could not claim that Abdullwahab has an intention to mislead or deceive his friend, that is, we could assume that he is being cooperative and wanted to imply something to his friend Ahmed, something that is additional to the piece of information which Ahmed has asked for.

Hence, the additional meaning here could be that Abdullwahab wished either the person whom he travelled with was awake so that they can talk and waste their time, or he wished he had another friend whom he travelled with instead of that who was sleeping all the time. For that matter, the speaker $(\mathrm{AB})$ has provided more information to the speaker $(\mathrm{A})$.

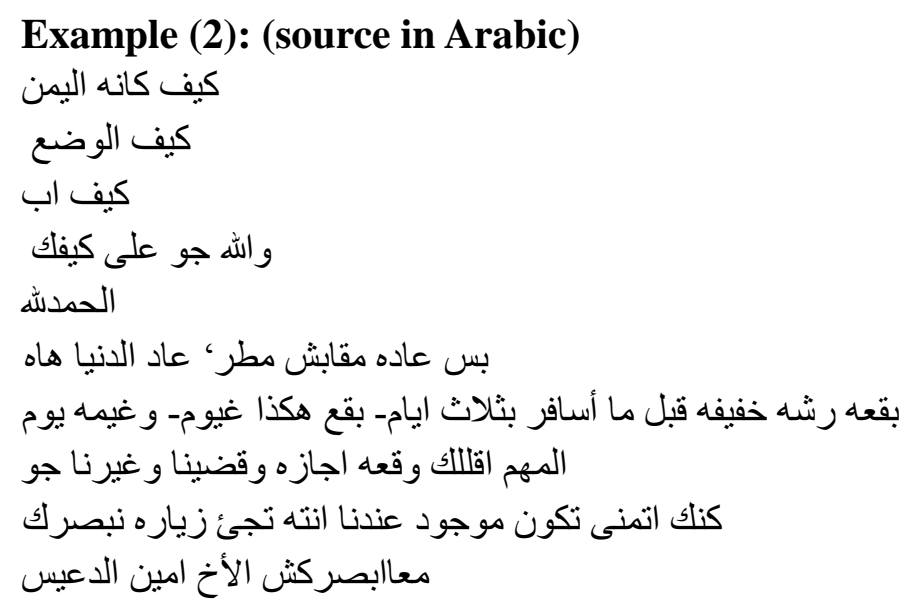


كنا نشتي نبصر الأخ أمين

\section{(Context)}

Ahmed has asked his friend Abdullwahab about Yemen. That is, how is the situation in Yemen in general and in Ibb city in particular?

Example (2): (translated into English)

\section{A: How is Yemen?}

How is everything and how is IBB?

AB: The weather is very nice.

Thanks God!

It has not started raining yet, still it looks not green.

It rained once but a little, it was cloudy, and they said it has rained three days before I have arrived to IBB.

Well, I have spent my holiday happily and I am very comfortable.

I wished you were there, to invite you and spend some time with you.

I did not met bother Ameen Alduais.

I wished I have met brother Ameen.

Again in this example (2) we can see how the maxim of quantity has been flouted. It has been mentioned above that a maxim of quantity is flouted when a speaker provides more or less information than the situation demands. Moreover, this happens intentionally in order to implicate an additional meaning in addition to the communicated meaning, but with no intention to mislead or deceive the other party. Here, we can notice that the speaker (A) has asked the speaker $(\mathrm{AB})$ for specific information. That is, the situation in Yemen in general and then in Ibb city in particular. Therefore, the speaker $(\mathrm{AB})$ has provided the needed information and also provided more information which the speaker (A) has not asked for.

Hence, it is not possible to claim that the speaker $(A B)$ was in one way uncooperative or in another way trying to mislead or deceive the speaker (A), because he has provided more information. According to Grice's theory we could assume that he wants to provide the other speaker with something else rather than the required information. This additional meaning (generated implicature) could be that he understood the question as that how did you spend your holiday. For that matter, he mentions that he wished to have met doctor Ameen and Ahmed to invite them to his house.

\section{Example (3): (source in Arabic)}

مو الفرق بين غذاء الملكات وال...

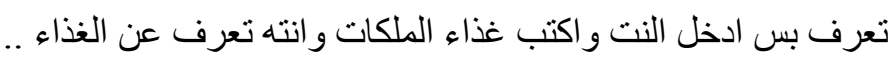

طيب غذاء الملكات.. طب عمر النحله الأفتر اضي تقريبا أربعه أثشر أو خمسهــ ما بين.

(Context)

Ahmed and his friend Abdullwahab were talking about honey in general. Abdullwahab said 
that he has honey called Queens' Food Honey which Ahmed doesn't know about or never have heard about. As a result, Ahmed is asking his friend about the main difference between this kind of honey and the normal honey which Ahmed does have.

Example (3): (translated into English)

A: what is the difference between queens' food (bees) and the...

AB: You know, just go through the internet and search for (Queens' food) and you will know about the food...well... queens' food. The age of a bee is about four months or five, in between.

We have mentioned earlier that Grice has introduced four principles or types of flouting the maxim. In the examples $(1 \& 2)$, we have discussed and illustrated how a maxim of quantity is flouted and an implicature has been generated. In these two examples, a new type of flouting the maxims is going to be introduced and illustrated, which is the maxim of quality.

Principally, a maxim of quality is flouted when a speaker provides either untrue information or information which he or she lacks adequate evidence for. Once again this happens intentionally by the speaker in order to imply an additional meaning and of course with no intention to mislead the other party.

However, we can notice here that the speaker (A) has asked for a particular kind of information which is the main difference between two types of honey: one is the normal honey and the other type called the queens food honey. Alternatively, the speaker (AB) provides information which explains the contents and the age of the queens of the bees and working-bees which is not actually the main difference between these two types of honey. Yet, we cannot claim that he is trying to mislead his friend Ahmed or provide him with wrong information. Instead, we can assume that he is being cooperative and he has made an attempt to provide his friend with the main difference between the two types of honey.

Thus, we could say that the additional meaning here is Abdullwahab knows the difference between these two types of honey and these types of honey are really different but he is lacking for the adequate evidence for what he is saying so that he made an attempt to bring as many explanations as possible.

\section{Example (4): (source in Arabic)}

السو اقين مو هم- سوريين؟

و احد .. سعودي- و الثاني تقريبا من ابين مدري منين...!

\section{(Context)}

Two friends: Ahmed and Abdullwahab were talking about Abdullwahab's journey to his country (Yemen) by bus. In the previous part of this conversation Abdullwahab has mentioned that there are two divers for the bus in order to corporate with each other, one sleeps and the other drives. Curiously, Ahmed wants to know the nationalities of the two drivers and he is asking his friend Abdullwahab about it. 


\section{Macrothink}

Example (4): (translated into English)

A: What are the nationalities of the drivers?

AB: One is Saudi and the other is may be from Abian governorate, or I am not sure.

Another example for flouting the maxim of quality by providing untrue information is the above one. The speaker (A) has asked specifically about the nationalities of the drivers of the bus which he has travelled by. Nevertheless, the speaker (AB) has suggested that one is Saudi and the other he did not know. Contradicting himself, the speaker (AB) has said at the end of his utterance that he is not sure about what he is saying.

Certainly, the speaker $(A)$ is not sure whether the speaker $(A B)$ meant he is not sure about the last piece of information or the whole provided information. That is, Ahmed is not sure whether his friend is doubtful about the nationality of the other driver or the two drivers. In spite of this, we could not claim that the speaker $(\mathrm{AB})$ was uncooperative or was trying to deceive his friend because he provides something which he lack enough evidence for. Instead we could assume that he was cooperative and was trying to provide an additional meaning.

The additional meaning which we could generate here is that Abdullwahab was annoyed with the question what nationalities do the drivers have. Yet, he did not directly state it, he provided his friend with predicted answers rather than information based on facts or certain knowledge.

Example (5): (source in Arabic)

أنقول ما عكنا نشتي العزومه هذي!

كيف زنوب- زنوبه (زينب)

(Context)

Ahmed is offering his friend Abdullwahab one more cup of coffee and Abdullwahab thought it is something not good to drink a lot on the cost of his friend Ahmed.

Example (5): (translated into English)

AB: You will say it was better not to make this invitation!

A: How is Zanoub- Zanoubah (Zainab)?

Have introduced with examples two types of flouting the maxim, we now look at the third type of these maxims which is the maxim of relation. In principle, a maxim of relation is flouted when a speaker unexpectedly but intentionally changes the main topic of the conversation by saying something irrelevant to the main topic of the conversation. However, this action of changing the conversation is not done randomly it is meant but not in order to betray or mislead the other party but to convey an extra meaning rather than the communicated meaning through the conversation.

Therefore, the speaker $(\mathrm{AB})$ was talking about the invitation of having coffee with his friend Ahmed. That is, Abdullwahab is considering drinking more than cup of coffee is impolite. 


\section{Macrothink}

Alternatively, Ahmed has abruptly changed the topic by saying something which not irrelevant to Abdullwahab's statement. As a result, we could assume that Ahmed is being cooperative though he has flouted the maxim of relation by providing irrelevant piece of information. Thus, it is important because it contains an additional meaning which could be in one way or another that he is saying to Abdullwahab it is not good to mention how many cups of coffee you drink even if it is on my own account; it suggests indirectly that you are considering me as a miser person.

\section{Example (6): (source in Arabic)}

هاه- ايه

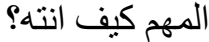

كيف الدراسه معك؟ كيف ال..... - كئ.

و الله الحمدلله تمام

بدأنا هذا الأسبوع

\section{(Context)}

Having coffee and sitting with each other, the two friends Ahmed and Abdullwahab were conversing with each other, each one is asking the other about what he is doing and how each is spending his time. This time, Abdullwahab is asking Ahmed about his study in the $1^{\text {st }}$ term and mainly his grades.

Example (6): (translated into English)

AB: Yes, what?

Most importantly, how are you?

How is your study? How is...

A: Thanks God, it is Ok

We have started just this week.

It has been mentioned above that the maxim of relation is flouted when a speaker provides irrelevant information to the main topic of the conversation or he or for one reason or another changes abruptly the main topic of the conversation. One more example for this case is the example (6). The speaker ( $\mathrm{AB}$ ) has asked the speaker (A) about his study. In real life, the speaker $(\mathrm{AB})$ knows well the speaker $(\mathrm{A})$ has just started studying the next term which indicated that he is not asking about the study itself but about the grades which the speaker (A) has got in the previous term.

Therefore, the speaker (A) has blatantly flouted the maxim of relation by saying something irrelevant to the directed question to him. That is, he should have said it directly that I have got this in that subject and that in this subject but he has just thanked God which is not related to the main topic of the conversation. Yet, we cannot claim that the speaker (A) is not being cooperative or he was trying to mislead his friend. Instead, we could assume that he was being cooperative and attempted to communicate or indicate an additional meaning.

Thus, the additional meaning could be that it indicates primarily that the speaker (A) was not 
satisfied with the grades he has got in the first term but he is thanking God. More meanings could be that he did not want to say the truth for his friend or he feels annoyed when he remembers the story of grades as he is not satisfied with his rate.

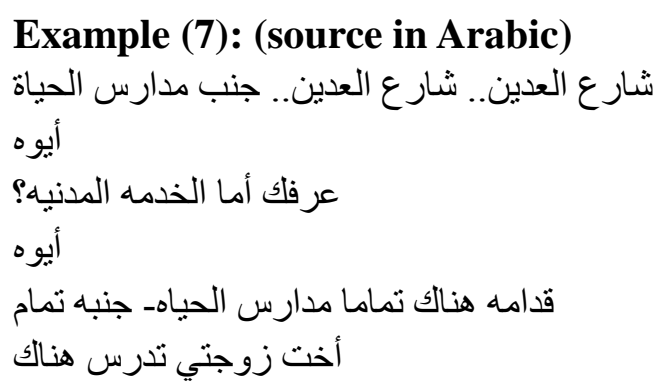

(Context)

Abdullwahab was talking to Ahmed about the things he did when he was in his country Yemen. In the previous part of this conversation, Ahmed has asked about the location of one of his relatives' home who is doctor Ameen Alduais. Abdullwahab is trying to describe the location for Ahmed.

Example (7): (translated into English)

AB: Odin Street, Odin Street, near to Alhiah School.

A: Yes?

AB: You know where the citizen service is? In front of it is Alhiah School exactly next to it. My wife's sister is teaching there.

Having introduced three types of flouting the maxim: Quantity, Quality and Relation, we now introduce the fourth type (principle), flouting the maxim of Manner. Fundamentally, a maxim of manner is flouted when a speaker is being disorderly, vague, ambiguous, or wordy in his or her reply to the other party (ies). Once again, and just as it has been mentioned above this happens purposefully and the result is a generated implicature or an additional meaning rather than the communicated meaning.

Example (7), however, illustrates how the speaker (AB) has flouted the maxim of manner. Mainly, Abdullwahab's friend was asking about the location of a person called Ameen Alduais and his answer should be as orderly and clear as possible as such information needs to be accurate and brief in order to help the receiver get the right piece of information he has asked for. Otherwise, the speaker $(\mathrm{AB})$ is not being orderly enough; he is providing more and more places in addition to some pieces of information which are not closely related to the main topic of the conversation which caused for his answer to be vague and disorderly. Despite this, we cannot claim that he was trying to mislead or even cheat his friend. Instead we could assume that he is being cooperative and trying to imply something else. This additional meaning could be that I need to tell you all these details in order to get you to the right location because I know that you are not good at locating places.

\section{Example (8): (source in Arabic)}




\section{MIMacrothink}

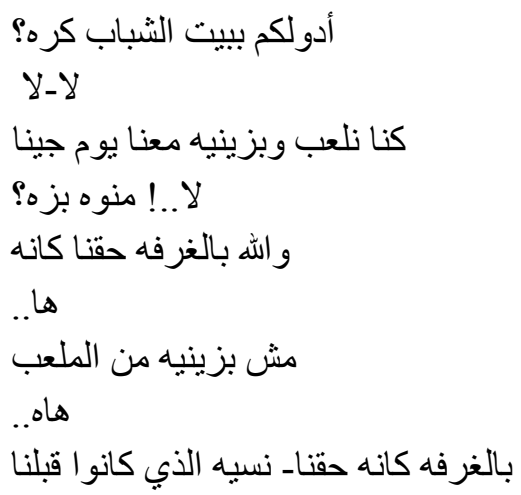

(Context)

While Abdullwahab has spent his holiday of the $1^{\text {st }}$ term in Yemen his home country, Ahmed has not travelled and he has spent his holiday in Madinah mainly at the Youths' House. Previously, the two friends were talking about playing football and Ahmed has mentioned that he has a ball which he has brought from the Youths' House. Abdullwahab is curious to know how Ahmed has got the ball, whether it has been given or taken.

Example (8): (translated into English)

AB: They have given you a ball in the Youth's House, haven't they?

A: No, no.

We were playing with it and we took it with us.

AB: No! Who has taken it?

A: I swear by God it was in our room.

AB: Ah!

A: we have not taken it from the playground.

AB: Ah!

It was in our room, it was forgotten by those who were living before us.

One more example about flouting the maxim of manner is example (8). It has been mentioned above that the maxim of manner is flouted when a speaker chooses deliberately to be vague, ambiguous, disorderly or not brief in his or her reply to the other party.

Ultimately, the speaker (AB) has asked the speaker (A) whether that ball which is in Ahmed's room has been given to them from the Youths' House where in he spent his holiday or it has been taken it from there. As a result, the speaker (A) has tried to answer his friend's question or fulfill his required information. Unfortunately, it seems that the speaker (A) fails to observe the maxim of manner by being vague in his reply to his friend. Put another way, the speaker (A) should have said whether they have taken it or even stolen it from there or not since he has already decided and stated that it was not given. Hence, we cannot claim that the speaker (A) is being uncooperative with his friend. That is to say, we could suppose that he is trying to implicate an extra meaning rather than the ball was taken or given. This extra meaning could be that we have made a mistake and took it from there so do not embarrass me more than that and let me say that we have stolen it because we actually did not mean to steal it, we thought it was forgotten and we have to take it. 


\section{Conclusion}

To sum up, this research-paper aimed at introducing one of the very influential theories in the field of Pragmatics (sociolinguistic studies); namely Grice's theory Conversational Implicature. The main point of the study was to test the applicability of Grice's supposed principles which are Quantity, Quality, Relation and Manner on another languages rather than English language. Therefore, the provided date was taken from the researcher's native tongue language which is Arabic language, mainly non-standard Arabic, Yemeni dialect and an idiolect spoken at IBB city, the city where in the researcher lives. Principally, Grice introduced in the Conversational Implicature theory two cases: one is called observing the maxims and it is considered as the least important one because all the maxims are easily observed and what is said is meant, the other case is non-observance of the maxim, within this case, there are five cases, one of them is flouting the maxims and it is considered as the most important one because what is said is not what is meant. More importantly, an additional meaning is generated whenever a maxim is flouted. For that matter, the researcher has limited his study to this case. Thus, it has been concluded that Grice's theory and principles do apply on the non-standard Arabic language and the principles which he has suggested seem to coincide in their applicability with Arabic language just like as it is in the English language. For one reason or another, this could suggest that Grice's theory of the Conversational Implicature in the new field of linguistics which is Pragmatics seems to be a universal theory which is may be applicable to all the world languages. Such a thing, however, empowers this theory and at the same time fulfills the main aim of this research-paper where in the researcher has argued in favor of the universality of Grice's theory.

\section{Acknowledgement}

Many thanks are due to Mr. Abdulwahab Mohammed (currently a BA student in the College of Physical Education and Sports, King Saud University, Riyadh, Saudi Arabia) who very cooperatively and willingly participated in this study, yet has allowed transparent analysis of all the recorded data for the purpose of academic research.

\section{References}

Black, E. (2006). Pragmatic Stylistics. Edinburgh: Edinburgh University Press Ltd.

CARSTON, R. (2002). Thoughts and Utterances: The Pragmatics of Explicit Communication. Blackwell: Blackwell Pubilishing.

Collinge, N. E. (Ed.). (1990). An Encyclopedia of Language. London: Routledge.

Leech, G. (1974). Semantics . Penguin: Penguin Books.

Thakur, D. (2001). Linguistics Simplified: Semantics . Thakurbari Road, Kadamkuan,Patna 800003 : Bharati bhawan (Publishers \& Distributers).

Thomas, J. (1995). Meaning in Interaction: an Introduction to Pragmatics. Longman, London and New 
York : Longman Group Limited .

Ward, L. R. (2005). The Handbook of Pragmatics. Blackwell: Blackwell Publishing.

Widdowson, H. G. \& Yule, G. (2008). Pragmatics. Oxford: Oxford University Press. 